\title{
ABSORPTIVE CAPACITY OF SIGNALS CAPTURED FROM ENVIRONMENT FOR INNOVATION
}

\author{
SHIRLEY A. SOUZA ${ }^{1}$ \\ (iD https://orcid.org/0000-0002-4496-7016 \\ DÉBORA E. P. SILVA ${ }^{2}$ \\ (iD) https://orcid.org/0000-0002-6981-3259 \\ ALINE F. ABREU \\ (iD) https://orcid.org/0000-0003-2275-5095
}

To cite this paper: Souza, S. A., Silva, D. E. P., \& Abreu, A. F. (2019). Absorptive capacity of signals captured from environment for innovation. Revista de Administração Mackenzie, 20(6). doi:10.1590/ 1678-6971/eRAMD190029

Submission: Mar. 9, 2019. Acceptance: July 11, 2019.

1 Universidade Federal de Sergipe (UFS), São Cristóvão, SE, Brazil.

2 Universidade Federal de Sergipe (UFS), São Cristóvão, SE, Brazil.

\section{(c) $\mathbf{B Y}$}




\section{ABSTRACT}

Purpose: This article aims to describe the absorptive capacity (ACAP) of textile manufacturing industrial companies of Sergipe state, Brazil, for the signals captured from the environment, indicating the need for innovation in response to changes in the market. The theoretical bases of absorptive capacity postulate that a company that develops this capacity has the ability to recognize the information value, assimilate it, and apply it for commercial purposes. They can develop skills that allow them to achieve competitive advantage.

Originality/value: From the theoretical point of view, the factors that stimulate the apparel companies to recognize, assimilate, transform, and exploit the external knowledge were listed. Regarding the practical contributions, the study can provide references to organizations wishing to extend or develop the absorption of new knowledge, so this can promote improvement in organizational activity and innovation.

Design/methodology/approach: For the study, it was built a qualitative data collection instrument. The instrument had been applied in seven companies with innovative characteristics when compared to the local competition. Companies are micro to medium-sized and develop innovations in process and marketing.

Findings: The result shows that the analyzed companies look for renewal of existing knowledge and assimilate the external information to adapt and transform their organizational strategies. The exploitation of knowledge occurs from relationships with customers and suppliers, prior knowledge of leadership and organization existing structure. Companies with best ACAP were those who faced direct competition. This fact has created incentives for the search for information to differentiate the companies and make them competitive.

\section{KEYWORDS}

Innovation. Absorptive capacity. Knowledge. Industrial companies. Sergipe. 


\section{INTRODUCTION}

The deep economic, social, and technological transformation that has been occurring over the last years, with the commercial opening of the country, has brought structural changes to Brazilian businesses. The result is a globalized market, in which there are no longer geographical barriers to products and services marketing. It has caused constant changes in marketing, such as changes in routines, processes, and business plans of several organizations. Such changes challenge companies to show themselves administratively and commercially competitive (Campos, Santos, \& Donadon, 2017; Negri, 2006; Rossi, Santos, \& Santos, 2017).

For Brazilian textile companies, these changes are even more significant. The sector is a segment with one of the greatest representations in Brazilian industry. According to the Associação Brasileira da Indústria Têxtil e de Confecção (Brazilian Textile and Apparel Industry Association) (2017), the textile industry was responsible, in 2017, for a turnover of BRL 51.58 billion; it is the second largest employing sector in the processing industry, behind food and drinks together; it is the second largest first jobs generator; there are 27.5 thousand formal businesses; and has almost 200 years in Brazil. However, over the years, it has been losing competitiveness and market share (Costa \& Rocha, 2009).

The incoming of Asian products with impracticable prices, because of the commercial opening, intensified the high competition in the domestic market and began to require companies of the sector to develop capacities to absorb changes, and generate innovation (Bruno, 2016). These transformations have generated the need to use company's internal capacities to monitor, capture, and follow the signals the environment emits about trends or market changes (Crossan \& Apaydin, 2009; Lawson \& Samson, 2001; Smith, Busi, Ball, \& Meer, 2008; Tang, 1999).

The information from the environment has fundamental importance, and the ability to acquire and exploit the knowledge, i.e., the absorptive capacity (Cohen \& Levinthal, 1989), started to have an essential role for organizations to develop and generate innovation.

The survival capacity of an organization depends on its ability to anticipate changes in its environment (Lesca \& Caron-Fasan, 2008). The capture of signals in the market provides information to enable businesses to make decisions to innovate and survive. Based on these assumptions, this article tries to describe the ability of textile and apparel companies of the 
state of Sergipe to absorb the signals captured from the environment. These signals stimulate innovation.

As occurred in other Brazilian states, Sergipe's apparel industrial companies were affected by the commercial opening. One of the effects of the process is a decline in the level of formal employment and in the number of businesses (Federação da Indústria do Estado de Sergipe, 2008). Since 2008, deep structural changes have occurred in the industry, with emphasis on operational units restructuring/modernization and information technology intensive use. For this reason, it is essential for these companies, the development of capacities to promote the renewal of their strategies and generation of innovations.

\section{INFORMATION AS A RESOURCE FOR THE PROCESS OF INNOVATION}

Lemos (2009) says the business environment has suffered a strong impact with the constant economic and technological changes. The speed the new market shapes itself, and technology and organizational forms are modified, has demanded to economic agents the ability to generate and absorb innovations. With the changes, it is possible to observe an increasing reduction in the production and consumption of goods.

Individuals, businesses, countries, and regions have sought to develop skills to acquire, learn, and transform knowledge into a competitiveness factor (Fosfuri \& Tribó, 2008; Lemos, 2009; Tidd \& Bessant, 2015). Knowledge is also a critical component in the innovation activity (Fosfuri \& Tribó, 2008), and can be originated from external sources. Even though companies, especially large companies, invest in internal research, the search for information beyond its borders contributes to remain them innovative and competitive (Garud, Tuertscher, \& Van de ven, 2013).

However, in order to capture information from internal and external environments, the company must have or develop organizational capacity to understand and explore opportunities (Bessant \& Tidd, 2009). To acquire information and convert them into innovations requires skills and monitoring practices of the signals generated by the environment. Knowing the scenario in advance allows the organization to adapt and change its strategy (Lesca, Janissek-Muniz, \& Freitas, 2003).

In order to ensure survival, the company needs to innovate. Innovation is a subject fairly discussed by economic and administration literatures, 
since the milestone of contributions of Joseph Schumpeter (1988). The researcher tried to understand its characteristics, sources, stimulators, and management process for the development of enterprises and the economy (Lemos, 2009).

The debate about the process intensifies, it is no more linear and with only one direction, and it starts to be accepted as a "complex structure of interaction between economic environment and technological change directions" (Lemos, 2009, p. 160). Muylder et al. (2015) consider the existence of a common link between the processes of innovation management and knowledge management, due to the company's capacity to absorb the knowledge. A process also understood as new knowledge implementation.

For Crossan and Apaydin (2010), innovation is related to acquisition, assimilation, and exploitation of novelty and added value in economic and social aspects. Innovation can be understood as a process and as a result (Bessant \& Tidd, 2009; Crossan \& Apaydin, 2010). As a process, innovation follows a sequence of activities that make it possible to transform ideas into reality. The innovation includes three steps: creation, development, and implementation of a new idea (Garud \& Tuertscher, 2013).

The company implements actions to "examine and analyse scenarios (internal and external) in order to capture and process potential signals of innovation" (Bessant \& Tidd, 2009, p. 34). These signals can be presented as a necessity from: opportunities from research activities; regulatory pressure from governments; or competition conduct. They correspond to the set of stimuli to which the company should react (Bessant \& Tidd, 2009).

For the Oslo Manual (Organização para a Cooperação e Desenvolvimento Econômico, 2018), the company innovates when it performs a change that impacts its working method, factors of production and/or results of productivity and performance. Following the definitions of the Oslo Manual, the kind of innovation can be classified into product, process, organizational and marketing innovation.

Bessant and Tidd (2009) added that the company, when building and developing its innovation process, should look for signals that enable the generation of innovation. These signals can arise in many different ways and many different places. To capture them, the company must have the tools. "Once captured the relevant innovation signals and taken the strategic decision to bet on some of them, the next step is the idea implementation, which requires the combination of different knowledge", i.e., the company should use the internal knowledge to turn the idea into reality (Bessant \& Tidd, 2009, p. 36). 
Vanhaverbeke and Cloodt (2006) argue that the acquisition of knowledge from internal and external sources for generation of innovation indicates that the process of generation of innovation is subsidized by organizational expansion of transactions of knowledge. The authors say the attention to external sources of knowledge does not reduce the need to understand how companies can generate and manage internal knowledge. The presence of external sources of knowledge does not imply the entrance of new ideas in an organization as an automatic or easy process. And the external knowledge can only be recognized, accessed and assimilated when companies develop new routines and change their organizational structure (Vanhaverbeke \& Cloodt, 2006).

Considering that knowledge is generated by the interaction between individuals and organizations, information only becomes useful and has meaning after interpreted by individuals (Chou, 2005; Perdomo, Lozada, \& Zúñiga, 2017). Once incorporated, knowledge and experience are carried out by means of multiple entities and mechanisms, such as culture and organizational identity, routines, policies, systems, documents, and individual's ability to integrate and absorb knowledge. The company may, then, generate a kind of knowledge difficult to imitate and socially complex.

To identify and take advantage of the benefits of new knowledge and opportunities depends on the organizational absorptive capacity (Chou, 2005; Cohen \& Levinthal, 1990; Jansen, Van Den Bosch, \& Volberda, 2005), as it is discussed in the next section.

\section{CONCEPTS AND DIMENSIONS OF ABSORPTIVE CAPACITY}

The absorptive capacity (ACAP), understood as essential to the accumulation of competencies and organizational learning, had its first theoretical model developed by Cohen and Levinthal (1990). From their work, several researchers broadened the construct (Camisón \& Forés, 2010; Fosfuri \& Tribó, 2008; Jansen et al., 2005; Lane, Koka, \& Pathak, 2006; Van Den Bosch, Van Wijk, \& Volberda, 2003; Zahra \& George, 2002), and applied it in several areas.

The model developed by Cohen and Levinthal (1989) defines ACAP as the company's ability to assimilate and apply new knowledge. It also highlights the importance of the implementation of the investments in research and development (R\&D) for the generation and maintenance of competitive advantage. For the authors, the investment in research 
has a double effect: it develops new processes and innovations in products; and develops and expands the company's ability to identify, assimilate and exploit the information available in the environment.

In their theoretical model, the authors determined the stock of knowledge of the company is composed of sums of internal knowledge (science and technology) with the external knowledge, assimilated and exploited. They highlight that the company should not passively assimilate the knowledge available externally, i.e., the company must be proactive, should invest in research (Cohen \& Levinthal, 1989).

Cohen and Levinthal (1989) also create a distinction between the absorptive capacity of an individual and the absorptive capacity of an organization. They also highlighted the internal mechanisms to foster communication and relationships between the members as an organizational aspect of absorptive capacity. In the following year, 1990, the same authors reviewed the construct and suggested ACAP is influenced by the level of prior knowledge existing in the company. With this perspective, the discussion focuses on internal mechanisms influencing ACAP, and it expands to three components: cognitive levels of individual members of the organization; historical trajectory; and the path chosen by the organization. The authors also discuss the role of external knowledge as a critical factor in the innovation process.

After ten years of the publication of the seminal article conceptualizing ACAP, Zahra and George (2002) propose a redefinition, recognizing ACAP as a dynamic capacity. The model defines ACAP as a set of processes and routines by which the company acquires, assimilates, transforms and exploits knowledge. In the model, ACAP is divided into potential absorptive capacity and realized absorptive capacity (Figure 3.1).

\section{(Figure 3.1)}

\section{MODEL OF ABSORPTIVE CAPACITY BY ZAHRA AND GEORGE}



Source: Zahra and George (2002). 
According to Zahra and George (2002), the dimensions of the potential absorptive capacity (PACAP) include knowledge acquisition and assimilation. The dimensions of the realized absorptive capacity (RACAP) include the ability to commercially processing and exploiting knowledge. It also comprehends the combination of newly acquired knowledge, incorporating it into the company's operations. The four dimensions of the ACAP are shown in Figure 3.2.

\section{(Figure 3.2)}

\section{ACAP DIMENSIONS}

\begin{tabular}{ll}
\hline \multicolumn{1}{c}{ Dimensions } & \multicolumn{1}{c}{ Definition } \\
\hline Acquisition & $\begin{array}{l}\text { The ability to identify and acquire external knowledge. It is influenced by the } \\
\text { intensity, speed, and direction of efforts used by the company in this activity. }\end{array}$ \\
\hline Assimilation & $\begin{array}{l}\text { The processes and routines that allow the company to analyse, process, } \\
\text { interpret, and understand the information acquired in the external } \\
\text { environment. }\end{array}$ \\
\hline Transformation & $\begin{array}{l}\text { The ability to refine or reformulate the acquired knowledge combined with the } \\
\text { existing knowledge, creating new ideas and recognizing new opportunities. }\end{array}$ \\
\hline Exploitation & $\begin{array}{l}\text { The ability of the company to incorporate the knowledge and apply it in their } \\
\text { activities, resulting in the creation of changes or new constructions of goods, } \\
\text { processes, systems or in the improvement of existing qualities. }\end{array}$ \\
\hline
\end{tabular}

Source: Zahra and George (2002).

According to Zahra and George (2002), the potential and realized absorption capacities are different and complementary capabilities. The knowledge exploitation requires its acquisition and, to transform and exploit it, it is necessary its acquisition and assimilation. Zahra and George's (2002) model differs from Cohen and Levinthal's (1990) theory in two aspects: first, the definition of absorptive capacity as a dynamic capacity inserted in business routines and processes; second, the establishment of four dimensions, adding the transformation dimension to the model of Cohen and Levinthal (1990).

As Zahra and George (2002), other researchers are trying, from the point of view of Cohen and Levinthal (1990), to explain the ACAP influence in organizational events. Consequently, the creation of an instrument for measuring the absorptive capacity has become the object of study of several authors (Fosfuri \& Tribó, 2008; Jansen et al., 2005; Zahra \& George, 2002). 
Schmidt (2005) extends the context of ACAP analysis to analyze how ACAP is developed in innovative companies from three kinds of knowledge: knowledge developed internally by the industry itself; knowledge developed by other industries; and knowledge developed by research institutions. Addressing the ACAP study for the Brazilian market and technology, Negri (2006) says the technological gap existing between companies in developed countries and companies in developing countries, such as Brazil, can be reduced by ACAP. For the author, if the technology transfers from developed countries to developing countries are faster and more efficient, the technological gap between them will be reduced faster, because their technical progress ability would strongly depend on the ability to exploit technological knowledge produced by developed countries companies.

Fosfuri and Tribó's (2008) studies found evidence that the cooperation in $\mathrm{R} \& \mathrm{D}$, acquisition of external knowledge, and inner experience in research are the essential background to the company's absorptive capacity. In another direction, Vega-Jurado, Gutiérrez-Gracia, and Fernández-de-Lucio's (2008) study advances about ACAP, suggesting the absorptive capacity is determined not only by the research and development activities, but also by factors influenced by organizational knowledge, formalization, and social integration mechanisms.

Advancing the discussion, Camisón and Fóres (2010) try to validate the construct, following Zahra and George's (2002) proposal, which divides ACAP in two dimensions. Their study tries to identify indicators to explain the ACAP capture. Camisón and Fóres' (2010) study stands out for two factors: first, integrating multiple elements analyzed by other researchers in their model, the result of an extensive review of literature; second, to empirically validate the dimensions proposed by Zahra and George (2002). The authors present a mechanism for the operationalization of the model.

Kostopoulos, Papalexandris, Papachroni, and Ioannou's (2011) studies found evidence that ACAP contributes to innovation and financial performance, but at different times. For the authors, if a company consistently creates and sustains closer relationships with suppliers, it will have better a position to identify and assimilate new external expertise. The complementarity of new knowledge acquired from external sources further expands these effects.

Other authors, such as Engelen, Kube, Schmidt, and Flatten (2014), reveal the moderating role of absorptive capacity to strengthen the company's entrepreneurial orientation and performance in turbulent markets. A company with a high degree of PACAP has strong communication and cooperation 
among its employees in organizational routines and can identify the most promising business segments. They can react to current trends in the industry. PACAP enables the company to interpret and assimilate information about potential threats, react quickly on failures of an innovative product, integrate new insights on the product and make the necessary corrections.

Garrido, Parente, Gonçalo, and Vasconcellos (2017) propose ACAP as variable mediator between past performance and innovative capacity. Under a management approach, the main contributions of this study are the linking of ACAP and internationalization to understand the company's innovative capacity. From ACAP, companies can exploit and make better use of the knowledge and opportunities.

From the studies analyzed, it is observed that the absorptive capacity is presented as a multidimensional construct and focuses attention on knowledge sharing, with a focus on ideas generation for solving problems and generating innovation. About the subject, it is understood that, in the process of knowledge acquisition, the company modifies its base resources and incorporates new skills, processes, and routines, which will be the support for the innovation process.

\section{METHODOLOGICAL PROCEDURES}

The selection of cases was made from consultations with the Federação da Indústria do Estado de Sergipe (2008) (Industries Federation of the state of Sergipe) and the Serviço Brasileiro de Apoio às Micro e Pequenas Empresas (Sebrae - Brazilian Service of Support to Micro and Small Business). For interviews, seven textile manufacturing industrial companies were selected, with at least one year of uninterrupted activities.

The data collection procedure involved documentary research and interviews with a structured guide. Managers responsible for industrial companies were interviewed. A specialist validates the structured interview. An interview guide to refine the roadmap was made. Figure 4.1 was built based on Zahra and George's (2002) model and the elements discussed in the studies about ACAP mentioned in the theoretical study. Figure 4.1 has dimensions, categories, and elements of analysis; they will be the basis for the study operationalization. 


\section{(Figure 4.1)}

DIMENSIONS, CATEGORIES, AND ELEMENTS OF ANALYSIS

\begin{tabular}{|c|c|c|}
\hline AC dimension & Category of analysis & Elements to observe \\
\hline \multirow{9}{*}{ Acquisition } & \multirow{3}{*}{ Sources of knowledge } & $\begin{array}{l}\text { Integration and internal relations and cooperation } \\
\text { and exchange of information between employees }\end{array}$ \\
\hline & & $\begin{array}{l}\text { Cooperation for study and partnership with other } \\
\text { institutions and companies }\end{array}$ \\
\hline & & $\begin{array}{l}\text { Opening for the environment and knowledge of the } \\
\text { competitor }\end{array}$ \\
\hline & \multirow{3}{*}{$\begin{array}{l}\text { Information search } \\
\text { mechanisms }\end{array}$} & Technological acquisition \\
\hline & & Exploitation of existing knowledge \\
\hline & & Use of computerised systems \\
\hline & \multirow{3}{*}{ Work practices } & Meetings and participation in decisions \\
\hline & & Trends monitoring \\
\hline & & Interface between functions \\
\hline \multirow{4}{*}{ Assimilation } & \multirow[t]{2}{*}{ Information sharing } & $\begin{array}{l}\text { Company's internal communication and assimilation } \\
\text { of technology }\end{array}$ \\
\hline & & Human resources and educational level of employees \\
\hline & \multirow{2}{*}{ Training } & Participation in training and tradeshows \\
\hline & & Realization of industrial benchmarking \\
\hline \multirow{6}{*}{ Transformation } & \multirow{2}{*}{$\begin{array}{l}\text { Application of employees' } \\
\text { experience }\end{array}$} & Assimilation and use of new technologies \\
\hline & & Job rotation (capacity for renewal and adaptation) \\
\hline & \multirow{4}{*}{ Communication processes } & Staff development program \\
\hline & & Socialization and connectivity (information exchange) \\
\hline & & Exchange of information through IT \\
\hline & & Existence of manuals and documents \\
\hline \multirow{5}{*}{ Exploitation } & \multirow{3}{*}{$\begin{array}{l}\text { Incorporation of } \\
\text { innovations }\end{array}$} & Commercial exploitation of new knowledge \\
\hline & & Acquisition of machinery, systems \\
\hline & & Application of acquired experience \\
\hline & \multirow{2}{*}{$\begin{array}{l}\text { Exploitation of patents } \\
\text { and trademarks }\end{array}$} & Registration of trademarks \\
\hline & & Development of patents \\
\hline
\end{tabular}

Source: Elaborated by the authors. 
The processing and analysis of data were performed by content analysis. In this study, the pre-analysis is a transcription of interviews in accordance with the questions performed and the organization of information following the constructs investigated, considering the most important points of each interview.

The transcription of recordings was made with the Media Play system. The organization and analysis of data collected were performed in the exploration phase, to relate the statements of the interviewees with the dimensions of the constructs investigated.

\section{ANALYSIS AND DISCUSSION OF THE RESULTS}

The selected industries are located in the state of Sergipe and are established in Aracaju, the capital of the State, and in the towns of Lagarto, Itabaianinha, and Tobias Barreto. The data collection occurred in person and the interviews were conducted in the second half of 2018, from August to November. Regarding the industries of the study, the existence ranged from 08 to 30 years, the number of employees between 14 and 110, and the interviewees had distinct academic levels. The companies received the identification of Alpha, Beta, Gamma, Delta, Omega, Epsilon, and Zeta.

According to the criteria established by Sebrae: three of the studied companies are micro industries - up to 19 employees hired; three of the studied companies are small industries - 34 to 70 employees; and one is a medium-sized industry - 110 employees.

\section{(Figure 5.1)}

DESCRIPTION OF THE COMPANIES INTERVIEWED

\begin{tabular}{lllccl}
\hline Industry & Location (city) & Industry section & $\begin{array}{c}\text { Number of } \\
\text { employees }\end{array}$ & $\begin{array}{c}\text { Existence } \\
\text { (years) }\end{array}$ & $\begin{array}{c}\text { Interviewee } \\
\text { academic levels }\end{array}$ \\
\hline 1 (Alpha) & Lagarto & Sports clothing & 45 & 20 & University - incomplete \\
\hline 2 (Beta) & Aracaju & Shirts & 16 & 26 & University \\
\hline 3 (Gamma) & Itabaianinha & Women's clothing & 34 & 8 & University \\
\hline 4 (Delta) & Itabaianinha & Women's clothing & 14 & 12 & University \\
\hline 5 (Omega) & Tobias Barreto & Bed linens & 110 & 30 & University \\
\hline 6 (Epsilon) & Itabaianinha & Fitness clothing & 70 & 10 & University \\
\hline 7 (Zeta) & Itabaianinha & Women's clothing & 15 & 11 & University \\
\hline
\end{tabular}

Source: Elaborated by the authors. 


\subsection{Potential absorptive capacity (PACAP)}

According to Zahra and George (2002), PACAP includes the organization's efforts for the acquisition and assimilation of new knowledge and to offer the company the ability to adapt to unstable environments. In all companies, actions internally developed to locate, identify, value, and acquire external knowledge were found.

\subsubsection{Acquisition}

To understand the mechanisms used by organizations in the first dimension - acquisition - three categories were analyzed: knowledge sources, information search mechanism, and working practices. In spite of the leaders informing they were not concerned about competition, all of them said they search for information on the market, through actions of monitoring opportunities and trends in the sector.

[...] we always look for what is on the market, what is coming, what the competition has as a differential or what I can be better than the competition. We look for, pursue and search on the internet (Alpha).

The search for information about the sector is centered in leaders and people responsible for the creation and development of the products. In addition, searches are driven by the demand for market "novelty" and can be implemented in organizations' systems, machinery or industrial design. The search for information by the companies studied proves the assertion of Garud et al. (2013), the external knowledge sources provide information to favor the generation of new ideas and create business opportunities.

[...] we are always in contact with our customer, looking for information. Sometimes we do not need to make questions, the client talks naturally and provides information. So, we always go to the analysis field, I will observe and modify with the perspective of the brand identity, if we find that it is feasible, if it is really going to meet a customer increased demand (Gamma).

Regarding the frequency of information searches, it varies according to the source used. There is no standard applied by the organization or the other companies analyzed. 
In relation to the most used sources, it can be observed a standard in the interviewees' answers. The sources mentioned were tradeshows and industry events, internet, clients, suppliers, representatives, and support institutions (Sebrae and National Confederation of Industry- NCI). Universities and study centers were not listed as knowledge sources by any company, and only Alfa informed that it does not make partnership with other companies.

[...] we had been looking for various brands in Germany, in other countries, I have discovered that one in Canada, it was the last signal. We bought it. In a São Paulo tradeshow, when we saw something from Germany, we started to check other things with our friends in São Paulo, and they told us about this machine (Omega).

Consistent with the researched literature, the diversity and the number of knowledge sources have enabled companies to access different and complementary knowledge to the existing one, in the organization, internally (Cohen \& Levinthal, 1990; Zahra \& George, 2002). To Zahra and George (2002), external sources are the main antecedents of ACAP to the company. However, the absence of internal R\&D and partnerships with study centers has highlighted a gap in the exploration of the potential of these sources and can be used for innovative project developments.

About the information search mechanisms, among all ways cited, only Beta and Omega did not highlight the importance of the internet to search for information. For all other companies, internet has been widely used, it is a low cost and highly responsive feature to show in advance the industry trends in other consumer markets: "[...] today the world is global, with internet access, you keep up with the major brands, those brands that develop products in the same segment" (Epsilon).

In relation to information ways, the activity of the customer satisfaction survey carried out by the commercial sector in companies Gamma and Delta must be highlighted; and partnerships with suppliers for product development and employees' training. This information enables the development of internal abilities, as well as builds trust relations between partners and customers, reinforcing the companies' image (Camisón \& Forés, 2010).

The practices adopted by the organizations researched, to disseminate knowledge and monitor trends to help in the acquisition of knowledge, reported by almost all companies - except Omega - for dissemination and information socialization was the meeting. It was not found evidence of the existence of explicit rules establishing models of behaviors among 
employees in the companies studied: "[...] when new information is acquired, it is disseminated in meetings, and through them occurs orientation" (Zeta).

In the companies studied, the employees' actions and the previous accumulated knowledge are valued. This value is a stimulus for employees' independent qualification and to search new external information. However, there is no clear and formal internal guidance on how each employee can be attentive and bring information from the market. The search for information in different moments is centered in leaders, and companies do not develop skills in their employees, regardless the area: "[...] all knowledge is communicated to employees by lectures and meetings, from experiences and studies. In these moments, although there are no incentives, the employees participate" (Beta).

From the points presented, it can be observed that the researched organizations search to develop actions to extend their initial knowledge about their area of expertise, developed mainly through their relations with the external environment.

\subsubsection{Assimilation}

The assimilation dimension deals with routines and processes that allow the company to analyze, interpret and understand the information acquired. The understanding of the assimilation dimension involved the analysis of two categories: information sharing and training.

In relation to information sharing, the studied companies reported meetings for presentation and discussion of new information. Companies Alpha, Gamma, and Delta hold monthly meetings. Beta's meetings occur sporadically because, according to the leader of information socialization, they occur in the daily practice in the areas (sectors/teams/units/departments/etc.): "[...] in the meetings, we analyse and, sometimes, just accept. The other day, a collaborator gave a suggestion of a new cutting way and, to be brief, with the change, the production increased 400 pieces" (Gamma).

The qualification of the organization's professionals helps the information sharing. The study conducted by Negri (2006) says that the greater the academic level of professionals of an organization, the larger the company's absorptive capacity. Corroborating this statement, Talebi and Tajeddin (2011) indicate higher levels of managers' education are essential for absorptive capacity, since this ability is strongly linked with the internal knowledge, technical experience and organizations' operation.

All companies analyzed presented professionals with an upper-level academic qualification in their team of managers. Among the leaders, only 
company Alfa does not have a leader with a higher level academic qualification (Figure 5.1). In the industries researched, the presence of leaders with high-level implicit knowledge, acquired in practical experiences in the sector, confirms the relational nature of knowledge as a factor to maximize the absorptive capacity.

Companies Alpha and Delta demonstrated structured and formalized routines through procedures and activities implementation manuals. It suggests the information obtained by these companies follow a determined flow, encouraging the assimilation.

[...] the informational documents make it easier. They are used for monitoring sales and production; without them it would be difficult to have a direction (Alpha).

[...] the consultancy in production contributed to identify the best way to perform the activity. This generated the workshop Medical Control of the Occupational Health Program, which is very important for the company (Delta).

Regarding the need for training, it was not found in the companies a structured routine for identification and implementation of employees' training. It is possible to realize that this need is defined by managers. When the need for training is detected, companies hire entities such as Sebrae and Federação da Indústria do Estado de Sergipe for courses and trainings.

[...] many employees came without experience, knowing nothing and they learn together. For example: we trained the cutting employee. He had no experience. Today he already knows a little, even for the market. He went through all processes (Delta).

In general, the companies analyzed presented skills in information systems and technologies applied to the sector in which they are. The finding corroborates the assertion of Camisón and Forés (2010) that these factors allow the dissemination of relevant information and help the decisionmaking process of the organization.

\subsection{Realized absorptive capacity (RACAP)}

The realized absorptive capacity is composed of two dimensions: transformation and exploitation. It comprises a combination of newly acquired knowledge, incorporating it into company operations (Zahra \& George, 2002). 


\subsubsection{Transformation}

The transformation dimension deals with the reformulation of the acquired knowledge with the existing knowledge. This study involves the analysis of two categories: employees' experience application and communication processes.

Specifically, about the factors favored by the experience application, in all cases studied, two factors can be highlighted: cooperation among employees and the practice of job rotation. A company with strong communication and cooperation between employees and suppliers enlarges its AC, the information exchange stimulates the internal knowledge expansion and encourages the search for innovation (Fosfuri \& Tribó, 2008; Negri, 2006). In the cases studied, all leaders said there is cooperation among organization employees and among suppliers. On Alpha company, the use of information technologies and the interactivity among the leaders and their teams build the two factors indicated by the leader as a catalyst for experiences exchange.

[...] when there is rotation, an employee follows another employee, from a different area, for a few days, to learn the process and perform the activities in another sector (Alpha).

[...] the job rotation allows employees to exchange experiences and learnings. This happens through informal conversations. For example, if there is a problem with the commercial area, we hold a meeting with all employees and discuss it. Everyone participates in the problem solution (Delta).

In relation to implementation of experiences, all the interviewees reported that, at some point, the company used the experience of its employees in its processes. Employee participation occurs by means of suggestions for the productive process, in product development or strategic decisions. The suggestions occur by formal meetings or informal conversations, and it has been a resource identified in companies, suggesting the ability to transform information into knowledge: "[...] when there is some challenge, or some need for improvement, the employees participate offering suggestions. They have already worked in other companies, then they bring their previous experiences" (Zeta).

Specifically, Delta already hired professionals whose previous experience was absorbed by the company, but this was not a pre-requisite for hiring. In 
other companies, Alpha, Beta, Gamma, and Omega, there were no examples of previous experiences application, although they inform them to absorb the experiences of their employees, even if this is not a requirement observed in hiring.

In the cases studied, the leaders' prior knowledge was crucial to the identification, in the market, of the source to be accessed and the recognition of the information value. Through suggestions given by the customer or by recognizing the purchase of a certain machine, it would produce a positive result and value to the organization.

About the decision-making process for product development and trends analysis, in all companies, respondents reported decisions are made by meetings. In Beta and Gamma, this process involves the participation of the leader and some employees, while in Alpha and Delta, decisions are restricted to the management group. In addition to meetings, the job rotation was another way, identified by the companies, to favor the implementation of previous experiences and the information communication, contributing to the external knowledge interpretation (Van Den Bosch, Van Wijk, \& Volberba, 2003): “[...] we hold monthly meetings, and, in them, there is information and news exchange" (Zeta).

The coordination of the flow of information is centered on the leader, aided by technological tools, such as computer programs and applications. WhatsApp and e-mail are tools used by all studied companies as external communication mechanisms with customers and suppliers. The computerized programs are used to help recording operational information and reports.

[...] our commercial sector uses WhatsApp, Instagram and Facebook for direct communication with the customer. WhatsApp is used to exchange information on sales, products and solve doubts. Social medias are used to strengthen the company's brand and expand markets (Gamma).

[...] from 2015 to 2017, to leverage the company's image marketing, Lucas came. He has experience in large markets, manages communication and image. We joined ideas and we are going to a new path for the company, to focus more on the image. When we treat the image, we expose, the access and the contact with the company growth. After Instagram, every single day, at least 06 potential customers contact us (Beta). 


\subsubsection{Exploitation}

This dimension deals with the organization's ability to expand and leverage its skills to generate financial gains from new processes, services, or products. For this study, the understanding of the scale exploitation involves the analysis of category incorporation of innovation and exploitation of trademarks and patents.

All the companies studied showed that knowledge application resulted in important incremental innovations (Crossan \& Apaydin, 2010; Organização para a Cooperação e Desenvolvimento Econômico, 2018). This demonstrates that the knowledge acquired was incorporated into the existing one. It also corroborates the literature, which says that the ability to incorporate the knowledge acquired, assimilated and transformed, gives the organization competencies to ensure their operations are refined and result in innovations (Fosfuri \& Tribó, 2008; Zahra \& George, 2002).

Companies Alpha, Gamma, and Delta demonstrated as results the generation of incremental innovations in productive processes and marketing. Beta innovated in product and service.

[...] the company invests in new technologies to meet the market demand and to differentiate itself from the regional competition. We sense a change in consumer behavior, check if we have the internal conditions to produce the products required by the new trend (Alpha).

[...] the new machinery has impacted both the existent productive processes regarding the products, quality and the conditions of work; and allowed more efficiency for the company (Omega).

[...] the largest investment that we did was really the cutting room. You cannot stop investing in your company. Today, all people talk about is Industry 4.0, artificial intelligence. My machine makes a lot of things - the biggest innovation deployed in the company (Epsilon).

All companies showed similarity in the way they acquired relevant information to stimulate these innovations. Although all of them have performed some kind of innovation, in none of the companies the innovations were patents or copyrights. About patents register, all interviewees reported that they do not exploit the information available in their database. The only action developed by these companies was their own brand registry in the 
National Intellectual Property Institute (Instituto Nacional de Propriedade Intelectual - Inpi).

This absence can be explained by the lack of articulation with universities and study institutes, as well as by the fact that protection in the form of patents has impacted more the textile sector. The absence of relationship with universities and study centers indicate that these companies have not identified the importance of such information as a resource to access technology and protect their industrial designs.

Innovations derived from the knowledge of leaders, and their ability to decide which acquisitions (machinery, systems, etc) and organizational changes were necessary for the companies' goals, what, according to Camisón and Forés (2010), indicates the utilization and knowledge exploitation capacity to respond to changes in the environment. Another aspect is that the innovations in the studied companies are presented as a need to adapt to an economic scenario, which requires the organizations to be more productivity and lower costs.

[...] there are three motivations for searching new knowledge: increased productivity, reduced costs, and the need to be updated (Beta).

[...] this modernization was decisive for the company to gain and maintain competitiveness in the market. Without the acquisition of the new system and machinery, the company probably would be closed now (Delta).

The main results of this study are summarized in Figure 5.2.2.1, which establishes the relative comparison between the absorptive capacity processes of the companies studied. 


\section{(Figure 5.2.2.1)}

\section{ACAP THEORETICAL MODEL FOR APPAREL INDUSTRIAL COMPANIES}

Textile industries

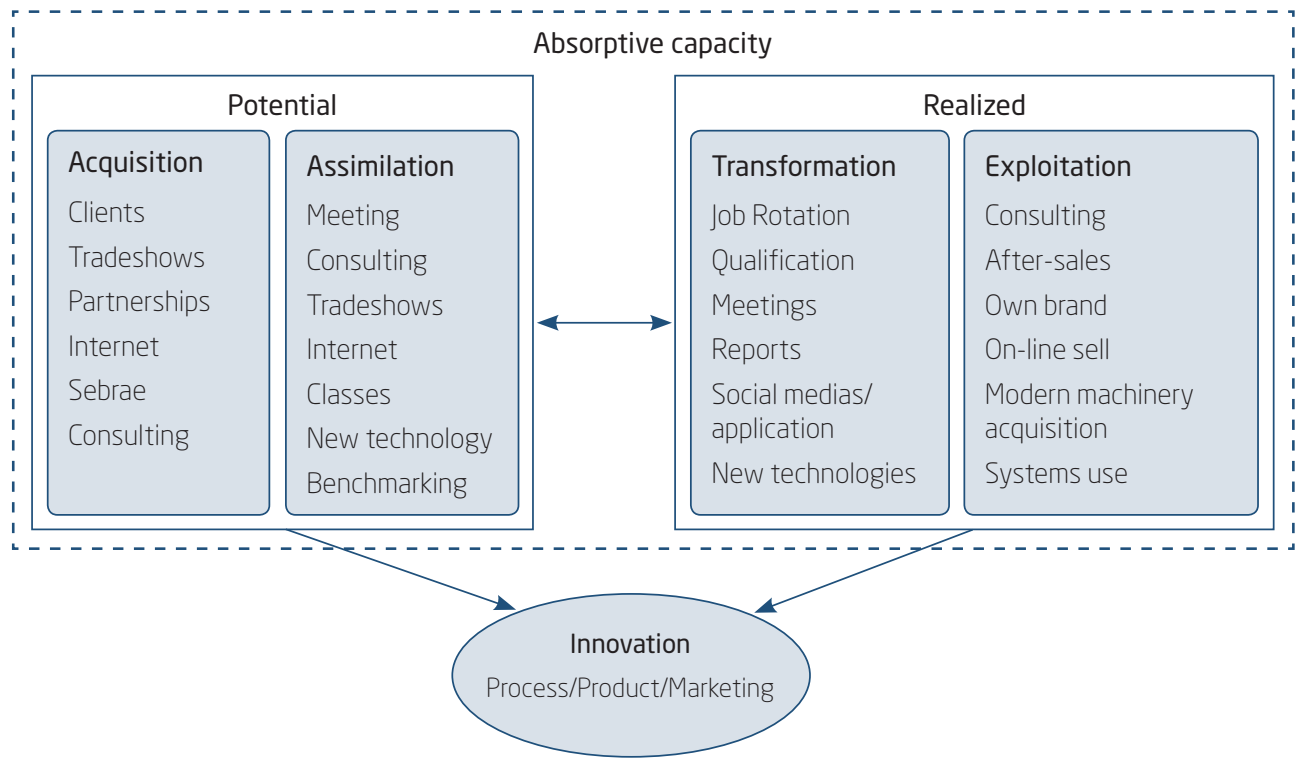

Source: Elaborated by the authors

\section{CONCLUSIONS}

This article aimed to describe the absorptive capacity (ACAP) of industrial companies from Sergipe state, textile manufacturing companies, for the signals captured from the environment indicating the need for innovation in response to changes in the market.

The acquisition of knowledge was not a bottleneck in the studied companies. On the contrary, the perception of the use of various existing ways leads to the conclusion that this step occurs with some planning. However, it is not possible to say the same for other dimensions: assimilation, transformation, and exploitation of knowledge.

The absence of structured mechanisms became evident in most cases, demonstrating the need for investments in these dimensions, mainly in the exploitation. It allows to check the ACAP impact on innovative processes of the organization. About the knowledge assimilation, the highlights are the role of the leaders as multipliers of knowledge (gatekeeper), and the organizational structure as factors to favour the development of this 
knowledge. Also, the flexible structure allows job rotation and exchange of knowledge.

For transformation, the job rotation and the opening for employees to express suggestions make easier the transfer of knowledge. From the results of this study, it can be highlighted the ability of knowledge exploitation directly related to: 1 . relations with customers and suppliers; 2 . prior knowledge of leadership; and 3. organizational structure. It is possible to say the companies' RACAP contributed to differentiate them from their competitors and face changes in the market.

In addition, results suggest ACAP of analyzed companies tends to be more addressed to direct competition; the greater the competition, the greater the tendency to search for information to be different and competitive.

Another point is innovation. Even being a term known by entrepreneurs, in only three companies the innovation strategy proved to be practiced consciously. For those managers, the effort to identify, acquire and transform the external knowledge became an important organizational investment and allowed innovation generation, even incremental. It confirms the relationship between absorptive capacity and innovation.

In this study, more than the scope of the objective, the findings identified important contributions. From the theoretical point of view, the factors that stimulate the apparel companies to recognize, assimilate, transform and exploit the external knowledge were listed (Figure 5.2.2.1). Regarding the practical contributions, the study can provide references to organizations wishing to extend or develop the absorption of new knowledge, so this can promote improvement in organizational activity and innovation.

The limitations of this study involve the impossibility of generalizing the results to other sectors. For future researches, the suggestion is the replication of this study in other sectors, in order to obtain a broader diagnostic and to understand how businesses from different sectors develop ACAP. It is also suggested to conduct researches to extend the information collection to suppliers and employees' perceptions.

\section{CAPACIDADE DE ABSORÇÃO DOS SINAIS CAPTURADOS DO AMBIENTE PARA INOVAÇÃO}

) RESUMO

Objetivo: Descrever a capacidade absortiva (ACAP) de empresas industriais sergipanas, do segmento de confecção têxtil, para os sinais captu- 
rados do ambiente que indicam necessidade de inovação em resposta às mudanças do mercado. As bases teóricas da capacidade absortiva postulam que a empresa que desenvolve essa capacidade possui habilidade em reconhecer o valor da informação, assimilá-la e aplicá-la para fins comerciais e, desse modo, desenvolver competências que lhe possibilitem alcançar vantagem competitiva.

Originalidade/valor: Do ponto de vista teórico, foram elencados os fatores que estimulam as empresas de confecções a reconhecer, assimilar, transformar e explorar o conhecimento externo. Quanto às contribuições práticas, a pesquisa pode fornecer referências às organizações que desejarem ampliar ou desenvolver a absorção de novos conhecimentos, de modo que estes promovam melhoria na atividade organizacional e inovação.

Design/metodologia/abordagem: As empresas são de micro a médio porte e desenvolvem inovações em processo e marketing. Para a realização da pesquisa, foi construído um instrumento de coleta qualitativo que foi aplicado em sete empresas com características inovadoras comparadas à concorrência local.

Resultados: O resultado mostra que as indústrias analisadas buscam renovação do conhecimento existente e assimilam as informações externas para se adaptar e transformar suas estratégias organizacionais. A exploração do conhecimento ocorre a partir das relações com clientes e fornecedores, do conhecimento prévio das lideranças e da estrutura existente na organização. As empresas que melhor apresentaram a ACAP foram as que enfrentaram concorrência direta, pois a sua presença criou estímulos para a realização da busca por informações para se diferenciarem e se tornarem competitivas.

\section{PALAVRAS-CHAVE}

Inovação. Capacidade absortiva. Conhecimento. Empresas industriais. Sergipe.

\section{REFERENCES}

Associação Brasileira da Indústria Têxtil e de Confecção (2017). Perfil do setor. Recuperado de https://www.abit.org.br/cont/perfil-do-setor 
Bessant, J., \& Tidd, J. (2009). Inovação e empreendedorismo. Porto Alegre: Bookman.

Bruno, F. S. (2016). A quarta revolução industrial do setor têxtil e de confeç̧ão: A visão de futuro para 2030. São Paulo. Estação das Letras e Cores.

Camisón, C., \& Fóres, B. (2010). Knowledge absorptive capacity: New insights for its conceptualization and measurement. Journal of Business Research, 63(7), 707-715. doi:10.1016/j.jbusres.2009.04.022

Campos, M. G., Santos, D. F. L., \& Donadon, F. A. B. (2017). Impacto dos investimentos em inovação na indústria brasileira. Revista Gestão Industrial, 13(3), 213-236. doi:10.3895/gi.v13n3.5774

Chou, S. W. (2005). Knowledge creation: Absorptive capacity, organizational mechanisms, and knowledge storage/retrieval capabilities. Journal of Information Science, 31 (6), 453-465. doi:10.1177/0165551505057005

Cohen, W. M., \& Levinthal, D. A. (1989). Innovation and learning: The two faces of R\&D. The Economic Journal, 99(397), 569-596. doi:10.2307/223 3763

Cohen, W. M., \& Levinthal, D. A. (1990). Absorptive capacity: A new perspective on learning and innovation. Administrative Science Quarterly, 35(10), 128-152. doi: $10.2307 / 2393553$

Costa, A. C. R., \& Rocha, E. R. P. (2009). Panorama da cadeia produtiva têxtil e de confecções e a questão da inovação. BNDES Setorial, (29), 159-202. Recuperado de https://web.bndes.gov.br/bib/jspui/bitstream/1408/ 1964/1/BS\%2029_Panorama\%20da\%20cad eia\%20produtiva\%20t\% c3\%aaxtil_P.pdf

Crossan, M. M., \& Apaydin, M. A. (2010). Multi-dimensional framework of organizational innovation: A systematic review of the literature. Journal of Management Studies, 47(6), 1154-1191. doi:10.1111/j.1467-6486.2009. 00880.x

Engelen, A., Kube, H., Schmidt, S., \& Flatten, T. C. (2014). Entrepreneurial orientation in turbulent environments: The moderating role of absorptive capacity. Research Policy, 43(8). 1353-1369. doi:10.1016/j.respol.2014. 03.002

Federação da Indústria do Estado de Sergipe (2008). Perfil da cadeia têxtil-confecções de Sergipe. Relatório final.

Fosfuri, A., \& Tribó, J. A. (2008). Exploring the antecedents of potential absorptive capacity and its impact on innovation performance. Omega, 36, 173-187. doi:10.1016/j.omega.2006.06.012 
Garrido, I. L., Parente, R. C., Gonçalo, C. R., \& Vasconcellos, S. L. (2017). Mantendo-se inovadoras: O papel do desempenho passado, da capacidade absortiva e da internacionalização. Brazilian Business Review, 14(6), 560-574. doi:10.15728/bbr.2017.14.6.1

Garud, R., Tuertscher, P., \& Van de ven, A. (2013). Perspectives on innovation processes. The Academy of Management Annals, 7(1), 773-817. doi:10.5465/ 19416520.2013.791066

Jansen, J. J. P., Van den Bosch, F. A. J., \& Volberda, H. W. (2005). Exploratory innovation, exploitative innovation, and ambidexterity: The impact of environmental and organizational antecedents. Schmalenbach Business Review, 57, 351-363. doi:10.1007/BF03396721

Kostopoulos, K., Papalexandris, A., Papachroni, M., \& Ioannou, G. (2011). Absorptive capacity, innovation and financial performance. Journal of Business Research, 64(12), 1335-1343. doi:10.1016/j.jbusres.2010.12.005

Lane, P. J., Koka, B. R., \& Pathak, S. (2006). The reification of absorptive capacity: A critical review and rejuvenation of the construct. Academy of Management Review, 31 (4), 833-863. doi:10.5465/AMR.2006.22527456

Lawson, B., \& Samson, D. (2001). Developing innovation capability in organisations: A dynamic capabilities approach. International Journal of Innovation Management, 5(3), 377- 400. doi:10.1142/S1363919601000427

Lemos, C. (2009). Inovação na era do conhecimento. Parcerias Estratégicas, 5(8), 157-180.

Lesca, H., \& Caron-fasan, M. L. (2008). Facteurs d'échec et d'abandon de projets de veillestratégique: Retours d'expérience. Revue SIM, 13(3), 17-42.

Lesca, H., Janissek-Muniz, R., \& Freitas, H. (2003). Inteligência estratégica antecipativa: Uma ação empresarial coletiva e pró-ativa. Revista Organização em Contexto, 4, 92-118.

Muylder, C. F., Silva, R., Soares, F. C., Parreiras, F., Pardini, D., \& Ziviani, F. (2015). Práticas de gestão do conhecimento e indicadores de geração da inovação. International Journal of Knowledge Engineering and Management, $3(7), 153-170$.

Negri, F. (2006). Determinantes da capacidade de absorção das firmas brasileiras: Qual a influência do perfil da mão de obra? In J. A. Negri, F. Negri, \& D. Coelho (Ed.). Tecnologia, exportação e emprego. Brasília: Ipea.

Organização para a Cooperação e Desenvolvimento Econômico (2018). Manual de Oslo. Diretrizes para coleta e interpretação de dados sobre inovação (4a ed.). Paris: OCDE. 
Perdomo, G. C., Lozada, N. B., \& Zúñiga, A. C. (2017). Absorptive capacity (AC): Knowledge generation and its evolution from variable to construct. Revista Espacios, 38(36), 1-10.

Rossi, M. C. T., Santos, G. F., \& Santos, A. L. M. (2017). Empresas estrangeiras e ganhos de produtividade setoriais e regionais na indústria brasileira. Revista Planejamento e Políticas Públicas, 48, 349-383

Schmidt, T. (2005). Absorptive capacity: One size fits all? Firm-level analysis of absorptive capacity for different kinds of knowledge. ZEW Discussion Papers, 1-37. doi:10.1002/mde.1423

Schumpeter, J. A. (1988). Teoria do desenvolvimento econômico: Uma investigação sobre lucros, capital, crédito, juro e ciclo econômico. São Paulo: Nova Cultural.

Smith, M. K., Busi, M., Ball, P. D., \& Meer, R. Van der (2008). Factors influencing an organisation's ability to manage innovation: A structured literature review and conceptual model. International Journal of Innovation Management, 12(4), 655-676. doi:10.1142/S1363919608002138

Talebi, K., \& Tajeddin, M. (2011). The adoption of new and innovative knowledge by small and medium enterprises of Iran: Opportunities and constraints for growth. African Journal of Business Management, 5(1), 39-49. doi:10.5897/AJBM10.366

Tang, H. K. (1999). An inventory of organizational innovativeness. Technovation, 19(1), 41- 51. doi:10.1016/S0166-4972(98)00077-7

Tidd, J., \& Bessant, J. (2015). Gestão da inovação (5a ed.). Porto Alegre: Bookman.

Van Den Bosch, F. A. J., Van Wijk, R., \& Volberda, H. W. (2003). Absorptive capacity: Antecedents, models and outcomes. Erim Report Series Research in Management, 5.

Vanhaverbeke, W., \& Cloodt, M. (2006). Open innovation in value networks. In H. Chesbrough, W. Vanhaverbeke, \& J. West (Ed.). Open innovation: Researching a new paradigm. Oxford, UK: Oxford University Press.

Vega-Jurado, J., Gutiérrez-Gracia, A., \& Fernández-de-Lucio, I. (2008). Analyzing the determinants of firm's absorptive capacity: Beyond R\&D. $R \& D$ Management, 38(4), 392-405. doi:10.1111/j.1467-9310.2008.00525.x

Zahra, S. A., \& George, G. (2002). Absorptive capacity: A review, reconceptualization, and extension. Academy of Management Review, 27(2), 185-203. doi:10.2307/4134351 


\section{AUTHOR NOTES}

Shirley A. Souza, Programa de Pós-Graduação em Administração (PROPADM), Universidade Federal de Sergipe (UFS); Débora E. P. Silva, Programa de Pós-Graduação em Engenharia da Produção (PPGEP), Universidade Federal de Pernambuco (UFPE); Aline F. Abreu, Faculty of Engeering, University of Waterloo (UW).

Shirley A. Souza is now Alumni of the Programa de Pós-Graduação em Administração (PROPADM) of Universidade Federal de Sergipe (UFS); Débora E. P. Silva is now associate professor at the Programa de Pós-Graduação em Administração (PROPADM) of Universidade Federal de Sergipe (UFS); and Aline F. Abreu is now sênior visiting professor at the Programa de Pós-Graduação em Administração (PROPADM) of Universidade Federal de Sergipe (UFS).

Correspondence concerning this article should be addressed to Shirley A. Souza, Avenida Engenheiro Gentil Tavares, 1166, Getúlio Vargas, Aracaju, Sergipe, Brasil, CEP 49055-260.

E-mail: shirley.aracaju@gmail.com

\section{EDITORIAL BOARD}

Editors-in-chief Janette Brunstein

Silvia Marcia Russi de Domênico

Associated Editor

Glória Charão Ferreira

Technical Support

Vitória Batista Santos Silva

\section{EDITORIAL PRODUCTION}

Publishing Coordination

Jéssica Dametta

Language Editor

Daniel de Almeida Leão
Layout Designer

Emap

Graphic Designer

Libro 